
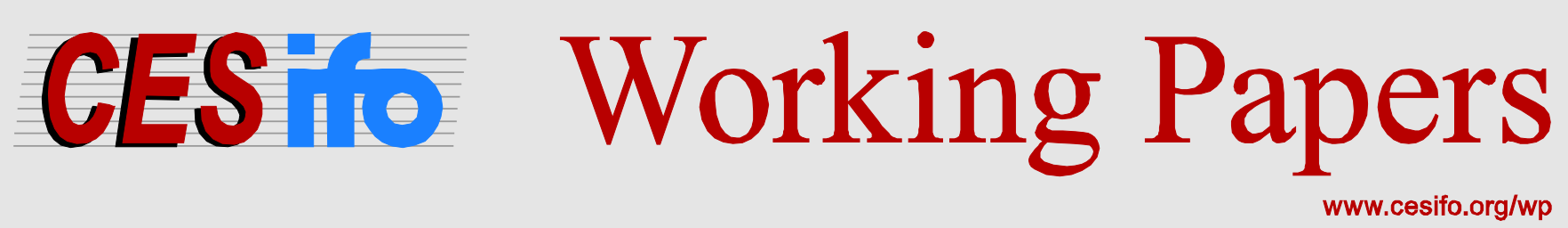

\title{
Progressive Tax Changes to Superannuation in a Lifecycle Framework
}

\author{
George Kudrna \\ Alan Woodland
}

CESIFO WORKING PAPER NO. 5645

CATEGORY 1: PUBLIC FINANCE

DECEMBER 2015

An electronic version of the paper may be downloaded

- from the SSRN website:

- from the RePEc website:

- from the CESifo website:

wWw.SSRN.com

Www.RePEc.org

www.CESifo-group.org/wp 


\title{
Progressive Tax Changes to Superannuation in a Lifecycle Framework
}

\begin{abstract}
This paper provides a quantitative analysis of hypothetical replacements of existing tax arrangements applied to superannuation (Australia.s term for private pensions) with traditional EET and TEE regimes. These taxation regimes exempt pension fund earnings from any taxation and tax either benefits or contributions progressively as regular incomes. By contrast, superannuation taxation features concessional flat tax rates on contributions and fund earnings, with benefits being generally tax free. Using an overlapping-generations model calibrated for Australia, we find that these hypothetical superannuation tax reforms have positive implications for vertical equity, as indicated by larger relative welfare gains and income improvements experienced by lower income households. The simulation results also show positive long run effects of the reforms on domestic assets as well as reduced pension expenditures.
\end{abstract}

JEL-codes: H550, E210, C680.

Keywords: compulsory saving, pension and tax reforms, dynamic OLG model.

George Kudrna*

Centre of Excellence in Population

Ageing Research (CEPAR)

Australian School of Business

University of New South Wales

Australia - Sydney, NSW 2052

g.kudrna@unsw.edu.au
Alan Woodland

School of Economics

UNSW Business School

University of New South Wales

Australia - Kensington, NSW 2033

a.woodland@unsw.edu.au

*corresponding author

September 2015

This research was conducted by the Australian Research Council Centre of Excellence in Population Ageing Research (project number CE110001029). The views expressed herein are those of the authors and are not necessarily those of the Australian Research Council. 


\section{Introduction}

Private pension pillars around the world benefit from concessional tax treatments that aim to increase private retirement incomes and household savings. As shown in Table 1, most countries tax their private pensions under the "Exempt-Exempt-Taxed" [EET] regime where contributions and fund income are exempt from any taxation but benefits are treated as ordinary income and taxed progressively. An alternative approach is the "Taxed-Exempt-Exempt" [EET] regime, which allows no deductions of contributions from gross income but then applies no further tax. By contrast, the existing tax treatment applied to Australia's superannuation (Australia's term for private pensions) features a flat tax rate on contributions and fund income, with benefits being generally tax free. As the statutory rate of this flat tax on contributions and fund income is 15 percent, the system is concessional for most income earners compared to progressive personal income taxation. ${ }^{1,2}$ The concessions, however, flow largely to high income earners, as demonstrated by Ingles (2009) and the Australian Future Tax Structure [AFTS] (2008, 2010). For instance, AFTS (2008, p.22) estimates that over 37 percent of concessional contributions go to only about 5 percent of Australians on very high incomes.

Table 1: Taxation of Private Pensions in Selected Countries

\begin{tabular}{|c|c|c|c|c|c|}
\hline \multicolumn{2}{|c|}{ EET } & \multirow{2}{*}{ TEE } & \multirow{2}{*}{ ETT } & \multicolumn{2}{|c|}{ TTE } \\
\hline EEt $[a]$ & EET & & & tTE & $\mathrm{ttE}$ \\
\hline France & Canada & Hungary & Denmark & New Zealand & Australia \\
\hline Germany & Finland & Luxembourg & Italy & & \\
\hline Ireland & Greece & United States & Sweden & & \\
\hline Japan & Iceland & (Roth IRA) & & & \\
\hline Korea & Netherlands & & & & \\
\hline Slovakia & Norway & & & & \\
\hline Spain & Poland & & & & \\
\hline Turkey & Switzerland & & & & \\
\hline United Kingdom & United States & & & & \\
\hline Belgium & Austria & & & & \\
\hline Portugal & Brazil & & & & \\
\hline Chile & & & & & \\
\hline
\end{tabular}

Notes: $\mathrm{E}=$ exempt; $\mathrm{T}=$ taxed under personal income tax; $\mathrm{t}=$ concessional tax or partial exemption; [a] Partial exemptions apply mainly to lump sums, with income streams often taxed as ordinary income; some countries such as the UK also impose limits on lump sum payouts.

Source: Yoo and de Serres (2004), OECD (2011).

\footnotetext{
${ }^{1}$ Note that the effective fund earnings tax rate is about 7.1 percent, which is due to imputation credits on dividend incomes and the capital gains tax discount (Yoo and de Serres, 2004).

${ }^{2}$ The Australian personal income taxation system is progressive with five tax brackets. The marginal tax rates currently range from zero to 45 percent (excluding the Medicare levy).
} 
Concerned with the vertical equity of Australia's superannuation tax arrangements, this paper provides a quantitative analysis of hypothetical replacements of the existing superannuation tax regime with the traditional EET and TEE tax regimes. Under both reforms, the existing flat tax rates on contributions and fund earnings that are currently paid by superannuation funds are abolished and either the withdrawals or the contributions are treated as ordinary income and taxed progressively at marginal tax rates in hands of households. We also examine the effects of a variant of the TEE regime recommended by AFTS (2010, pp. 84-85), which, in addition to the progressive taxation of contributions, includes (i) a flat-rate tax offset set such that the majority of taxpayers do not pay more than 15 percent tax on their contributions and (ii) a reduction of the statutory tax on fund earnings to 7.5 percent.

It is well known that under certain conditions the EET and TEE approaches are equivalent, that is, a shift to either the EET or TEE regimes would have the same effects on the present value of superannuation tax revenues and the lifetime behaviour of utility maximising households (see Kingston and Piggott (1993) or Creedy and Guest, 2008a). However, there would be no general equivalence for a pension or tax policy change that would be unanticipated by households and where tax rates would differ over the lifecycle (i.e., progressive taxation), which are some of the aspects incorporated in our modeling.

Australia's superannuation and its taxation arrangements have undergone many changes over the last decade. Probably the most significant change to superannuation taxation was the abolition of the superannuation benefit taxation for people aged 60 years and over, which was implemented in July 2007. While this change made the superannuation taxation simpler, it has an adverse effect on vertical equity of the system (see Bateman and Kingston, 2007). The fiscal effects of this reform were examined by the Institute of Actuaries Australia [IAA] (2007) and Davidson and Guest (2007), both projecting low fiscal costs of the implemented benefit tax abolition because of already highly preferential tax treatments of superannuation benefits in the pre-reform system.

Prior to the 2007 superannuation changes, many retirement income commentators and industry experts called for the move towards the traditional EET regime (see, for example, ASFA (1998) and Doyle et al., 1999) and some proposed abolishing the flat tax on contributions (for example, Clare, 2006). Horne (2002) assessed the ASFA (1998) proposal, arguing that it would increase savings and improve vertical equity. The analysis 
of the shift to the EET regime by Doyle et al. (1999) show only a small net loss in tax revenues as the revenue loss from the abolition of contribution and fund earning taxes is partly offset by imposing the marginal income tax rates on superannuation benefits. Atkinson et al. (1999), using a cohort micro-simulation model, find that the traditional EET regimes scores better in terms of intra-generational equity and overall progressivity than the concessional TTT regime in Australia at that time. Their main finding, however, is that the assumed behaviour at retirement (i.e., whether the superannuation savings are paid out as an annuity or a lump-sum) has much stronger effects on the redistributive measures than the superannuation tax structure.

The theoretical basis for the analysis of a policy change to private pension taxation is provided by Creedy and Guest (2008a). Using a three period, household model, they study behavioural effects of various superannuation tax policy changes on consumption, labour supply and savings and show that, for example, the benefit tax abolition would reduce saving and increase labour supply. Creedy and Guest (2008b) employ a computable overlapping generations (OLG) model to examine macroeconomic and welfare impacts of the 2007 abolition of the benefit taxation in Australia. Based on their simulations, this policy change favours middle-aged and older workers more than younger households, and reduces national savings. Their policy recommendations to (i) correct the first issue with the abolition of benefit taxation is to increase marginal tax rates on higher incomes that would fall more heavily on middle-aged cohorts and to (ii) deal with the second concern is to increase public saving through lower transfers or higher taxes to offset reduced household saving.

There is also a large body of international literature that uses computable OLG models to examine the economic effects of voluntary tax-deferred retirement saving accounts (see, for example, Imrohoroglu et al. (1998), Fehr et al. (2008) and Nishiyama, 2011). In general, these studies find positive effects on national wealth, capital stock and long run welfare, although these effects vary greatly due mainly to different assumptions about government budget balancing policy instruments. Fehr et al. (2008) not only assess the effects of tax-deferred or front-loaded accounts taxed under the EET regime but also the implications of tax-exempt or back-loaded accounts taxed under the TEE regime. They show that increases in national wealth are significantly greater with front-loaded accounts, which burden (benefit) old (young) rich households more than front-loaded accounts. 
The quantitative analysis of the superannuation taxation reforms in our paper also builds on computable OLG models. We use an extended version of the small open economy OLG model developed by Kudrna and Woodland (2011) that includes a detailed disaggregation of households into income quintiles linked to the ABS (2007) data and allows for gradual withdrawals of superannuation savings. Compared to Creedy and Guest's (2008b) model, our model includes intra-generational household heterogeneity, life-uncertainty, endogenous retirement and, most importantly, a richer structure of Australia's fiscal and retirement income systems. While Creedy and Guest (2008b) examine the effects of eliminating the concessional tax rates on either contributions or fund earnings or benefits, we evaluate the effects of the replacements of these concessional superannuation tax rates with the progressive income taxation applied to either benefits or contributions. Compared to Fehr et al. (2008) who assess the introduction of voluntary tax-preferred retirement accounts, we analyse the reforms to the concessional taxation of already established mandatory superannuation. The main goal of our paper is to assess how these hypothetical but radical reforms to superannuation taxation affect welfare and net incomes of households of different income classes (vertical equity) and of different ages (inter-generational equity). We also provide macroeconomic implications for the simulated superannuation tax reforms.

Our simulation results indicate that the examined reforms to superannuation taxation improve vertical equity and reduce income inequality, as shown by greater relative gains in welfare and net income shares for lower income households and by a lower Gini coefficient. These findings provide support for the proposal by ASFA (1998) to apply the progressive income taxation to superannuation benefits and for the proposals by AFTS (2010) and Ingles (2009) to tax the mandatory contributions as ordinary income. The reforms also have important inter-generational implications. Specifically, under the EET tax regime, older generations suffer from large welfare losses as their private pensions are treated as regular income and taxed at marginal income tax rates. Compared to the other two taxation reforms, the shift to EET regime, however, leads to greater long run welfare gains for all income types due to significant reductions in the assumed budget-balancing consumption or income tax rates. We also show positive long run effects of the reforms on domestic assets and reduced public pension expenditures, which are significant especially under the shift towards the EET tax regime. Similar effects on national wealth were 
obtained by Fehr et al. (2008) for the introduction of voluntary front-loaded (EET) accounts in Germany.

In the next section, we provide a technical description of our economic model. Section 3 reports on the calibration of the model and compares the benchmark steady state equilibrium solutions with Australian data. Section 4 presents the simulation results for the three reforms to superannuation taxation, concentrating on equity and macroeconomic implications. Section 5 considers the long run effects of the superannuation taxation reforms under the assumption of a higher superannuation guarantee (SG) rate. Finally, Section 6 offers some concluding remarks and suggestions for future research.

\section{The model}

We construct a computable general equilibrium model with overlapping generations for the analysis of the superannuation taxation reforms. The model builds on Kudrna and Woodland (2011) and is extended to (i) include a detailed disaggregation of households into income quintiles based on the ABS (2007) data and to (ii) allow for gradual withdrawals of superannuation savings rather than assuming lump sum payouts. ${ }^{3}$

The model is essentially a small open economy type of Auerbach and Kotlikoff's (1987) OLG model, whose variants have been used worldwide by many researchers to analyse various tax and pension policy reforms. In Australia, Kulish et al. (2010) used a closed economy model to analyse macroeconomic consequences of population ageing and Creedy and Guest (2008b) applied an open economy model to simulate changes to the superannuation tax regime. Computable OLG models with stochastic incomes were employed by Tran and Woodland (2011) and Cho and Sane (2011) to study the effects of policy changes to Australia's means tested pension. Compared to the aforementioned models, our model is specified to include major aspects of Australia's superannuation, means tested age pension and progressive income taxation, which, combined with household heterogeneity by both age and income type, is crucial for the analysis of distributional effects of the investigated superannuation tax reforms.

\footnotetext{
${ }^{3}$ Allowing phased withdrawals of superannuation savings is an important improvement, which is based on the fact that in 2009 the value of superannuation benefits paid as phased withdrawals exceeded for the first time the value of lump sums received (Bateman and Piggott, 2011).
} 


\subsection{Households}

We consider a model economy that is populated by sequences of cohorts distinguished by age $a$ and income type $i$. In particular, there are 70 generations aged from 21 to 90 years at any time $t$, with each generation consisting of the lowest, second, third, fourth and highest quintiles of households. Every year, a new generation aged 21 years enters the model structure and faces random survival with a maximum lifespan of 70 years, while the oldest generation aged 90 years dies. Random survival is given by the conditional survival probabilities denoted by $s_{a}$. We use a stationary demographic setup with a constant population growth rate, $n$, which together with survival probabilities, gives time-invariant cohort shares, $\mu_{a}=\left[s_{a} /(1+n)\right] \mu_{a-1}$.

Each $i$-type household who begins her economic life at time $t$ is assumed to optimally choose consumption, $c$, and leisure, $l$, at each age and when to retire from workforce to maximise the expected lifetime utility function given by

$$
\max _{\left\{c_{t+a-21}^{i}, l_{t+a-21}^{i}\right\}} \frac{1}{1-1 / \gamma} \sum_{a=21}^{90} S_{a} \beta^{a-21} u\left(c_{t+a-21}^{i}, l_{t+a-21}^{i}\right)^{1-1 / \gamma}
$$

subject to the within period budget constraint written as

$$
\begin{array}{r}
A_{a, t}^{i}=(1+r) A_{a-1, t-1}^{i}+w_{t} e_{a}^{i}\left(1-l_{a, t}^{i}\right)+A P_{a, t}^{i}+S B_{a, t}^{i} \\
+S T_{a}^{i}+B_{a, t}^{i}-T\left(y_{a, t}^{i}\right)-\left(1+\tau^{c}\right) c_{a, t}^{i}
\end{array}
$$

where $\gamma$ is the intertemporal elasticity of substitution, $u(c, l)$ denotes annual utility, with any future utility being discounted by the subjective discount factor, $\beta$, and the unconditional survival probability, $S_{a}=\prod_{j=21}^{a} s_{j-1}$.

In the per period budget constraint $(2), A_{a, t}^{i}$ denotes the stock of ordinary private assets for type $i$ household at the end of age $a$ and time $t$, which equals the assets at the beginning of the period, plus the sum of interest income, $r A_{a-1, t-1}^{i}$, labour earnings, $w_{t} e_{a}^{i}\left(1-l_{a, t}^{i}\right)$, age pension, $A P_{a, t}^{i}$, superannuation pension, $S B_{a, t}^{i}$, social transfer payment, $S T_{a}^{i}$, and bequest receipts, $B_{a, t}^{i}$, minus the sum of income taxes paid, $T\left(y_{a, t}^{i}\right)$, and consumption expenditures, $\left(1+\tau_{t}^{c}\right) c_{a, t}^{i} \cdot{ }^{4}$ Labour earnings are the product of labour

\footnotetext{
${ }^{4}$ The social transfers, $S T_{a}^{i}$, are assumed to be paid to households in the lowest to the fourth income quintile aged younger than 65 years (see Section 3 for the details).
} 
supply, $1-l_{a, t}^{i}$, and the hourly wage, $w_{t} e_{a}^{i}$, where $w_{t}$ is the market wage rate for a person with unit efficiency and $e_{a}^{i}$ is the age- and income-specific earnings ability variable. The labour supply is required to be non-negative, $1-l_{a, t}^{i} \geq 0$. Taxable income, $y_{a, t}^{i}=w_{t} e_{a}^{i}\left(1-l_{a, t}^{i}\right)+r A_{a-1, t-1}^{i}+A P_{a, t}^{i}$, comprises labour earnings, investment income and the age pension. The accidental bequests, $B_{a, t}^{i}$, are assumed to be equally redistributed to all surviving $i$-type households aged between 45 and 65 years.

Households are assumed to be born with no wealth and to exhaust all accumulated wealth at the maximum age of 90 years, so that $A_{20, t}^{i}=A_{90, t+70}^{i}=0 .{ }^{5}$ We also impose borrowing constraints by requiring $A_{a, t}^{i} \geq 0$ to prevent younger households from borrowing against their superannuation payouts, as the superannuation guarantee legislation prohibits such borrowing.

\subsection{Private and public pensions}

Australia has a three pillar retirement income system with the targeted, publicly provided age pension, the mandatory and fully funded superannuation guarantee scheme and other long term private saving, including housing and voluntary superannuation. The model incorporates the main aspects of the two publicly stipulated pillars - age pension and mandatory superannuation. We begin with compulsory superannuation as the superannuation assets and the incomes these assets generate affect the age pension payments for the eligible households through the means testing.

The superannuation guarantee mandates employers to contribute currently 9 percent of gross wages into the employee's superannuation fund. We assume that mandatory contributions are made on behalf of all working households at the contribution rate, $c r$, from their gross labour earnings, $w_{t} e_{a}^{i}\left(1-l_{a, t}^{i}\right)$. These contributions net of the contribution $\operatorname{tax}, \tau^{s} \times c r$, are added to the stock of superannuation assets, $S A_{a, t}^{i}$, that earns fund income at the after-tax interest rate, $\left(1-\tau^{r}\right) r$. Superannuation assets are assumed to be kept in the fund until households reach age 60 . The households aged 60 years and over can draw down their superannuation savings as pensions, $S B_{a, t}^{i}$, which become part of the perperiod budget constraint defined in (2). The stock of superannuation assets accumulates

\footnotetext{
${ }^{5}$ The assumption of no planned bequests is based on Gokhale et al. (2001) who document a number of studies that found strong empirical evidence against inter-generational altruism, supporting the view that bequests are largely accidental.
} 
in the fund according to

$$
S A_{a, t}^{i}=\left[1+\left(1-\tau^{r}\right) r\right] S A_{a-1, t-1}^{i}+\left(1-\tau^{s}\right) c r \cdot w_{t} e_{a}^{i}\left(1-l_{a, t}^{i}\right)-S B_{a, t}^{i},
$$

where $\tau^{r}$ is the effective earnings tax rate and $\tau^{s}$ denotes the statutory contribution tax rate. If eligible households decide to collect superannuation pensions, $S B_{a, t}^{i}$, then these pensions are subject to the maximum and minimum withdrawal limits. ${ }^{6}$

The age pension, $A P_{a, t}^{i}$, is paid to households aged 65 years and over provided that they satisfy the means test. The means test comprises the income test, $A P i_{a, t}^{i}$, and the asset test, $A P a_{a, t}^{i}$, with the test that results in lower age pension payments (i.e., binding test) applied. The means testing of the age pension can be expressed as

$$
\begin{aligned}
& A P_{a, t}^{i}=\min \left\{A P i_{a, t}^{i}, A P a_{a, t}^{i}\right\} \\
& A P i_{a, t}^{i}=\max \left\{\min \left\{p, p-\theta\left(\widehat{y}_{a, t}^{i}-I T\right)\right\}, 0\right\} \\
& A P a_{a, t}^{i}=\max \left\{\min \left\{p, p-\phi\left(\left(A_{a, t}^{i}+S A_{a, t}^{i}\right)-A T\right)\right\}, 0\right\},
\end{aligned}
$$

where $p$ is the single rate of the maximum age pension, $\theta$ is the income taper rate, $\phi$ represents the annual asset taper rate, IT denotes the income threshold and AT is the asset taper rate. The income assessed under the pension income test, $\widehat{y}_{a, t}^{i}=r\left(A_{a-1, t-1}^{i}+\right.$ $\left.S A_{a-1, t-1}^{i}\right)+0.5 \times w_{t} e_{a}^{i}\left(1-l_{a, t}^{i}\right)$, consists of interest earnings generated from superannuation and non-superannuation assets and half of labour earnings. ${ }^{7}$

\subsection{The rest of the model}

The model is a general equilibrium model which, in addition to the household and pension sectors, includes the production, government and foreign sectors.

The production sector comprises a single producer that represents a large number of perfectly competitive firms. This representative producer maximises the present value of

\footnotetext{
${ }^{6}$ The maximum limit of 10 percent of the superannuation balance applies only to working households. The minimum limits are aged based. These are 4 percent of the balance for households younger than 65 years, 5 percent for those aged $65-74,6$ percent for 75-79 years old, 7 percent for 80-84 years old, 9 percent for 85-89 years old and 11 percent for those 90 years old.

${ }^{7}$ We follow the means testing rules for superannuation as closely as possible (see FaCSIA, 2009). The superannuation assets are assessed in full under the asset test and the interest income generated by superannuation assets is subject to the income test, reflecting the means testing applied to shortterm income streams. In fact, the deeming approach is applied to these pensions and other financial investments with the pre-specified rates of return on these assets.
} 
all future profits discounted at the world interest rate, $r$, specified by

$$
\max \sum_{t=0}^{\infty} D_{t}\left[\left(1-\tau^{f}\right)\left(F\left(K_{t}, L_{t}\right)-C\left(I_{t}, K_{t}\right)-I_{t}-(1+c r) w_{t} L_{t}\right)\right]
$$

by choosing capital, $K_{t}$, labour input, $L_{t}$, and net investment, $I_{t}$, subject to the (per capita) capital accumulation equation of the form

$$
(1+n) K_{t+1}=I_{t}+(1-\delta) K_{t}
$$

where $D_{t}=(1+n)^{t} /(1+r)^{t}$ accounts for discounting and population growth, $\tau^{f}$ stands for the corporation tax rate, $F\left(K_{t}, L_{t}\right)$ represents the production of gross output, $C\left(I_{t}, K_{t}\right)$ gives the adjustment cost function and the term $(1+c r) w_{t} L_{t}$ denotes the total wage bill, which also includes mandatory contributions.

The government is assumed to maintain a balanced budget, which includes the pension expenditures, $A P_{t}$, social transfers, $S T$, and public consumption, $G$ on the expenditure side and the tax revenues from household income, $T R_{t}^{Y}$, consumption, $T R_{t}^{C}$, and superannuation, $T R_{t}^{S}$, and firm's profits, $T R_{t}^{F}$ on the income side. The per capita pension expenditures and tax receipts from households and firms in period $t$ are given by

$$
\begin{aligned}
A P_{t} & =\sum_{i=1}^{5} \omega_{i} \sum_{a=65}^{90} \mu_{a} A P_{a, t}^{i} \\
T R_{t}^{Y} & =\sum_{i=1}^{5} \omega_{i} \sum_{a=21}^{90} \mu_{a} T\left(y_{a, t}^{i}\right) \\
T R_{t}^{C} & =\sum_{i=1}^{5} \omega_{i} \sum_{a=21}^{90} \mu_{a} \tau_{t}^{c} c_{a, t}^{i} \\
T R_{t}^{S} & =\sum_{i=1}^{5} \omega_{i} \sum_{a=21}^{60} \mu_{a}\left[\tau^{s} \cdot c r \cdot w_{t} e_{a}^{i}\left(1-l_{a, t}^{i}\right)+\tau^{r} \cdot r S A_{a-1, t-1}^{i}\right] \\
T R_{t}^{F} & =\tau^{f}\left(Y_{t}-\delta q_{t} K_{t}-(1+c r) w_{t} L_{t}\right),
\end{aligned}
$$

which are the weighted averages of each component across households, with weights given by the intra-generational shares, $\omega_{i}$, and cohort shares, $\mu_{a} \cdot{ }^{8}$ In the per capita corporation tax revenue, $Y_{t}$ is output net of adjustment costs and $\delta q_{t} K_{t}$ represents depreciation of the value of the capital stock. The government budget is assumed to be balanced in every time period by adjusting the consumption tax rate, $\tau_{t}^{c}$, or through proportional changes to the personal income tax schedule, $T\left(y_{a, t}^{i}\right)$.

\footnotetext{
${ }^{8}$ Note that government consumption and social transfers are assumed to be constant, with the per capita social transfers equal to $S T=\sum_{i=1}^{4} \omega_{i} \sum_{a=21}^{64} \mu_{a} S T_{a}^{i}$.
} 
The foreign sector is represented by the international budget constraint. The constraint equates capital flows with the current account and can be written in per capita terms as

$$
(1+n) F D_{t+1}-F D_{t}=T B_{t}-r F D_{t}
$$

where $F D_{t}$ to be the per capita net foreign debt at the beginning of time $t, T B_{t}$ is the trade balance (or net export) and $r F D_{t}$ represents the interest payments on net foreign debt. The domestic interest rate, $r$, is exogenous in this small open economy model and equal to the world interest rate.

The endogenous variables of the model are determined such that all agents optimise their objective functions subject to any constraints and such that all markets clear in every period. The clearing conditions for labour, capital and output markets are

$$
\begin{aligned}
L_{t} & =\sum_{i=1}^{5} \omega_{i} \sum_{a=21}^{90} e_{a, t}^{i}\left(1-l_{a, t}^{i}\right) \mu_{a} \\
q_{t} K_{t} & =\sum_{i=1}^{5} \omega_{i} \sum_{a=21}^{90}\left(A_{a, t}^{i}+S A_{a, t}^{i}\right) \mu_{a}-F D_{t} \\
Y_{t} & =\sum_{i=1}^{5} \omega_{i} \sum_{a=21}^{90} c_{a, t}^{i} \mu_{a}+I_{t}+G_{t}+T B_{t},
\end{aligned}
$$

where $q_{t}$ is the price of capital (i.e., Tobin's $q$ ) that is obtained by solving the firm's profit maximisation problem.

\section{Calibrating the model}

The model is calibrated to the key Australian aggregates averaged over the five-year period ending in June 2010. We assume a stationary demographic environment with the constant population growth rate, $n$, set to current 1.8 percent per year. The population growth rate together with the male survival probabilities, $s_{a}$, taken from the 2007-09 life tables (ABS, 2010a) generates the existing old aged dependency ratio of 0.2 . The intra-generational shares, $\omega_{i}$, are equal to 0.2 for each income class because of the income quintiles used by ABS (2007). Below we discus intra-generational differences among households, present the per-period utility and production functions and report the values for the model parameters. We also provide a comparison of the model generated solutions with Australian data for some variables. 


\subsection{Income heterogeneity among households}

We consider five income types of households in each generation that differ by their exogenously given earnings ability and social transfer payments (excluding the age pension).

The earnings ability is the potential wage earned with all time endowment allocated to work. Using the estimated lifetime wage function for males with completed high school education from Reilly et al. (2005) and the income distribution shift parameter, $\zeta^{i}$, the earnings ability variable, $e_{a}^{i}$, is constructed as

$$
e_{a}^{i}=\zeta^{i} \times e^{2.235+0.04(a-17)-0.00067(a-17)^{2}}
$$

where $\zeta^{i}$ is set to 0.26 for the lowest quintile, 0.55 for the second quintile, one for the third quintile, 1.52 for the fourth quintile and 2.63 for the highest quintile. These values are the ratios of the private incomes of lower and higher quintiles to the private income of the third quintile, calculated from ABS (2007) - Table 7, p.22. Hence, the earnings ability profile for middle income households (i.e., those in the third quintile) is taken from Reilly et al. (2005) and the profiles for lower and higher income quintiles are shifted down and up to approximate the private income distribution in Australia. ${ }^{9}$

In order to match not only private income but also gross total income for each income quintile, we assume that households receive social transfers, denoted by $S T_{a}^{i}$ in equation (2). These payments, which are assumed to be constant and received by households (except for those in the highest quintile) aged younger than 65 years, are calculated as follows. First, we use the ABS (2007) data to derive the share of social transfers in gross total income for each eligible quintile. These shares are 0.44 for the lowest quintile, 0.3 for the second quintile, 0.15 for the third quintile and 0.06 for the fourth quintile. Then, we calculate the value of social transfers for eligible households in the benchmark steady state such that these payments together with the endogenous age pension yield the aforementioned shares in their lifetime gross income.

\footnotetext{
${ }^{9}$ We also assume the earnings ability for each income class after age 65 to decline at a constant rate to reach zero at age 90 as Reilly et al. considered only workers aged 15-65 years.
} 


\subsection{Preferences and technology}

Our choices of the annual utility and production functions and of the parameter values are standard in the literature. The per-period utility function takes the constant elasticity of substituton (CES) form

$$
u(c, l)=\left[c^{(1-1 / \rho)}+\alpha l^{(1-1 / \rho)}\right]^{1 /(1-1 / \rho)},
$$

where the intra-temporal elasticity of substitution, $\rho$, is set to 0.9 and the value for the leisure distribution parameter, $\alpha$, is 1.4. The remaining parameters in the lifetime utility (1) are the inter-temporal elasticity of substitution, $\gamma=0.4$, and the discount factor, $\beta=0.99$, with its value chosen to generate the capital output ratio of 3 (ABS, 2010b).

The technology is described by the standard CES production function

$$
F\left(K_{t}, L_{t}\right)=\kappa\left[\varepsilon K_{t}^{(1-1 / \sigma)}+(1-\varepsilon) L_{t}^{(1-1 / \sigma)}\right]^{[1 /(1-1 / \sigma)]}
$$

where the technology constant, $\kappa=0.88$, is calibrated to reproduce the market wage rate that is normalised to one in the benchmark steady state equilibrium. The elasticity of substitution in production, $\sigma=0.87$, and the capital intensity parameter, $\varepsilon=0.45$, are calibrated via the producer's first order conditions to match the interest rate and national account data for factor shares. The exogenous interest rate is set to 4 percent, which is the same rate as in Creedy and Guest (2008b). Following Fehr (2000), the adjustment cost function is assumed to be quadratic in net investment and given by

$$
C\left(I_{t}, K_{t}\right)=0.5 \psi\left(I_{t} / K_{t}-(n+\delta)\right)^{2} K_{t}
$$

where the value for the capital depreciation rate, $\delta$, that is set to target the investment capital ratio of 0.09 (ABS, 2010b) is 7.2 percent and the adjustment cost parameter of $\psi=10$ is taken from Auerbach and Kotlikoff (1987). We also target the ratio of net foreign debt to capital stock of 0.195 , reflecting net foreign ownership of about 19.5 per cent of Australia's capital stock (ABS, 2010b). 


\subsection{Policy parameters}

Table 2 reports the values for taxation and retirement income policy parameters. The values for the age pension and superannuation parameters are those applicable in September 2009. The age pension eligibility age is 65 years. The consumption tax rates is set to the statutory GST rate of 10 percent. We then compute the "tax base" parameter to replicate the average ratio of this tax revenues to GDP, which was 0.0389 over the five-year period ending in June 2010 (Commonwealth of Australia, 2011). The product of the statutory tax rate and the computed tax base parameter give the effective rates on consumption, $\tau^{c}=6.94 \%$. The corporation tax rate is set to the statutory rate of 30 percent and the government budget is assumed to be balanced with no government debt.

Table 2: Values of Policy Parameters in Benchmark Steady State Model

\begin{tabular}{lcc}
\hline Description & Value & Source \\
\hline Statutory consumption tax rate [GST] & 0.1 & Data \\
Statutory corporation tax rate & 0.3 & Data \\
Consumption tax base parameter & 0.694 & Calibrated[a] \\
Single rate of maximum pension (annual) & $\$ 17,469$ & Data \\
Income test threshold (annual) & $\$ 3,976$ & Data \\
Assets test threshold & $\$ 307,000$ & Data \\
Income reduction (taper) rate & 0.5 & Data \\
Assets reduction (taper) rate (annual) & 0.039 & Data \\
Superannuation contribution rate & 0.09 & Data \\
Superannuation contribution tax rate & 0.15 & Data \\
Superannuation earnings tax rate & 0.071 & Data[b] \\
\hline Notes: [a] The product of this tax base parameter and the statutory GST rate of 10 percent gives the effective \\
consumption tax rate of $6.94 \%$ that appears in the households' budget constraint; [b] This rate is roughly value
\end{tabular}

The model incorporates the differentiable approximation function of the Australian progressive personal income tax schedule in 2009-10. The approximation income tax, $T(y)$, is a function of taxable income, and it takes the following form:

$$
\begin{aligned}
T(y) & =t_{5}(y)-t_{5}\left(y t_{1}\right) \exp \left(\sum_{z=1}^{M-1}-(0.1)^{z} \nu_{z} \times \frac{y^{z}}{z}\right), z=1, \ldots, M-1, \\
t_{5}(y) & =m_{5}\left(y-y t_{5}\right)+\operatorname{tax}_{5}
\end{aligned}
$$

where $\nu_{z}=\left(\nu_{1}, \nu_{2}, \nu_{3}, \nu_{4}\right)$ is a parameter vector, $M$ denotes the number of tax brackets $(M=5), y t_{1}$ and $y t_{5}$ are the lowest and highest tax thresholds $\left(y t_{1}=0\right.$ and $y t_{5}=180$, expressed in $\$ 1,000), m_{5}$ is the top marginal tax rate $\left(m_{5}=0.45\right)$ and $\operatorname{tax}_{5}$ is the tax 
payable at the highest threshold $(t=54.55$, expressed in $\$ 1,000)$. The parameter vector $\nu_{z}=\left(\nu_{1}, \nu_{2}, \nu_{3}, \nu_{4}\right)$ is estimated by nonlinear least squares using the Stata software. We construct a grid of equally spaced incomes in the range $[0,200.5]$ and the corresponding income taxes payable based on the 2009-10 Australian tax schedule, with both variables expressed in units of $\$ 1,000$. The obtained parameter estimates are $\nu_{z}=(0.1446,0.0160$, $-0.0049,0.0003)$.

\subsection{Computation and benchmark steady state solution}

After specifying the parameter values, we compute the solution to the benchmark steady state equilibrium, using the GAMS software. ${ }^{10}$ Our algorithm applies the iterative GaussSeidel computational method that was suggested by Auerbach and Kotlikoff (1987). The steps carried out to solve for the steady states and the transition paths are listed in Kudrna and Woodland (2011). In this subsection, we outline the way of dealing with the non-convexity of the household budget set that is caused by the age pension means test. We follow Altig et al. (2001) to handle the kinked households' budget constraints and identify households that choose to locate at the kinks in particular periods by evaluating their income assessable under the pension income test. If the assessable incomes are close (rounded to 6 decimal places) to the income threshold of the pension income test, we set these incomes exactly to that threshold. By doing that we put such households exactly at kinks in each period in which being at a kink is optimal.

\footnotetext{
${ }^{10}$ We use GAMS software also to compute the transition paths of the superannuation taxation reforms.
} 
Table 3: Benchmark Model and Australian Data Comparison

\begin{tabular}{lcc}
\hline Variable & $\begin{array}{c}\text { Benchmark } \\
\text { model }\end{array}$ & $\begin{array}{c}\text { Australia } \\
{[\mathrm{a}]}\end{array}$ \\
\hline Expenditures on GDP (percent of GDP) & & \\
$\quad$ Private consumption & 56.12 & 56.22 \\
Investment & 27.01 & 27.38 \\
Government consumption & 15.58 & 17.88 \\
Trade balance & 1.29 & -1.3 \\
Government indicators (percent of GDP) & & \\
Age pension expenditure & 2.89 & 2.7 \\
Personal income taxes & 12.31 & 11.49 \\
Corporation taxes & 5.08 & 5.27 \\
Consumption taxes (GST revenue) & 3.89 & 3.89 \\
Superannuation taxes & 1.05 & 0.8 \\
Targeted calibration ratios & & \\
Capital-output $(K / Y)$ & 3 & 3 \\
Investment-capital $(I / K)$ & 0.09 & 0.09 \\
Foreign debt-capital $(F D / K)$ & 0.195 & 0.195 \\
Net income share & & \\
Lowest quintile & 0.069 & 0.075 \\
Second quintile & 0.121 & 0.125 \\
Third quintile & 0.184 & 0.171 \\
Fourth quintile & 0.243 & 0.229 \\
Highest quintile & 0.384 & 0.401 \\
Gini coefficient & 0.336 & 0.326 \\
\hline Notal Tre &
\end{tabular}

Notes: [a] These are 5-year averages over period ending in June 2010.

Source: Our simulations, Commonwealth of Australia (2011), ABS (2010b), ABS (2011).

Table 3 shows the results for the key macroeconomic ratios and household net income variables generated by the benchmark steady state solution of the model and provides a comparison with the actual data. The distribution of net incomes across the household quintiles and the Gini coefficient match very closely the actual data. ${ }^{11}$ The comparison of model generated and actual macroeconomic indicators also indicates that the model replicates the Australian economy fairly well. The components of domestic aggregate demand are close to their actual values expressed in percent of GDP, except for the trade balance, whose positive value is implied by the calibration target for the net foreign debt to capital ratio. Similar conclusions can be drawn for the displayed government indicators, apart from the government revenues from the superannuation taxes. The difference between the model and actual revenues from the superannuation taxation is due to the full maturity of the superannuation system that we assume in the model. ${ }^{12}$

\footnotetext{
${ }^{11}$ Note that the actual net income shares and the Gini coefficient in net income were obtained from ABS (2011) as averages over the five-year period ending in June 2010.

${ }^{12}$ Note that compulsory superannuation (i.e., superannuation guarantee) was introduced in 1992 with initial 3 percent contributions, which were gradually increased to the existing rate of 9 percent in 2002 .
} 


\section{Dynamic simulations of superannuation tax reforms}

In this section we numerically evaluate the three hypothetical reforms to superannuation taxation: (i) shift to the EET taxation regime, (ii) shift to the TEE taxation regime and (ii) implementing the AFTS proposal. Under the shift to the EET regime, the existing concessional tax rates on superannuation contributions and fund earnings paid by the superannuation fund are abolished, with the superannuation withdrawals being added to ordinary taxable income and taxed progressively at marginal income tax rates. The second reform - the shift to the TEE regime - also eliminates the existing concessional superannuation taxes, but it is the mandatory superannuation contributions that are included in ordinary taxable income and taxed progressively at marginal income tax rates. The third examined reform - the AFTS proposal - follows the TEE regime by treating superannuation contributions as ordinary taxable income. In addition, the proposal includes a 15 percent tax offset to contributions for all households and a reduction of the statutory tax on fund earnings to 7.5 percent. ${ }^{13}$ The reforms are expected to have implications for the government budget. As mentioned, we make adjustments either to the consumption or income taxation to maintain a balanced government budget. Specifically, we adjust the consumption tax rate under the consumption tax adjustments and make proportional changes to the progressive income tax schedule (thus proportionally raising or lowering average and marginal income tax rates) under the income tax adjustments.

The following discussion of the simulation results concentrates on the equity and macroeconomic implications of the three superannuation tax reforms. We first provide an overview of the key results and then we discuss the results in more detail.

\subsection{Overview}

All three examined reforms to superannuation taxation basically consist of two parts. The first part is to abolish the concessional 15 percent tax rate on mandatory contributions and to either fully eliminate the effective fund earnings tax of 7.1 percent for the EET and

The model assumption of the 9 percent mandatory contributions paid to households over their whole working life also generates higher ratios of superannuation assets to GDP and to total assets. Thus, it should be emphasised that the superannuation taxation reforms are examined in the environment of a fully mature superannuation system.

${ }^{13}$ Note that the effective fund income tax rate is reduced from 7.1 percent to 3.55 percent under this policy change. 
TEE regimes or to partially eliminated this tax for the AFTS proposal. These changes favour greatly the superannuation assets that households can draw down from the age of 60 onwards. The resulting increases in national wealth, saving and interest incomes upon reaching the eligibility age of 60 years for the age pension mean that the income and/or assets tests become more binding for potential age pension recipients and hence that the government expenditures on the age pension decline. In that sense, there has been a substitution between the age pension and superannuation as retirement supports, which is significant especially under the shift towards the EET taxation regime. ${ }^{14}$

The second part of the simulated reforms is to treat either the withdrawals (for the EET regime) or the contributions (for the TEE regime and the AFTS proposal) as ordinary taxable income. Consequently, the average income tax base increases, which generates larger revenues from income taxation and allows for budget equilibrating reductions in the consumption tax rate or average income tax rates. ${ }^{15}$ Under the EET regime, the budget equilibrating tax instruments are lower over the entire transition path because of increased labour supply of younger cohorts, which has positive effects on their ordinary non-superannuation assets. The decrease in the consumption or income tax rates is shown to be only temporary for the other two taxation reforms, with the refundable superannuation tax offset paid under the AFTS proposal implying higher budget equilibrating tax rates relative to those under the TEE reform.

The progressive income tax treatment of superannuation benefits or contributions is behind improvements in vertical (or intra-generational) equity and reductions in income inequality, which are demonstrated by greater gains (or smaller losses) in welfare and net income shares for lower income households and lower values of the Gini coefficient. In terms of the inter-generational implications, older generations experience significant welfare losses under the EET regime, as their superannuation pensions are taxed at marginal income tax rates. This contrasts with somewhat higher welfare or only small welfare losses under the TEE regime and the AFTS proposal for older cohorts, who are affected only indirectly through the budget equilibrating tax changes. In the long run,

\footnotetext{
${ }^{14}$ Note that the policy simulations of eliminating concessional tax rates on either contributions or fund earnings or benefits by Creedy and Guest (2008b) assume universal age pension benefits and thus are incapable of capturing the effects of a superannuation tax policy on the publically-provided age pension.

${ }^{15}$ Note that the income tax base (i.e., taxable income) increases for older households under the EET regime and for younger and middle-age households under the other two reforms. These households then face higher average and marginal income tax rates. The budget equilibrating reduction or increase under the income tax adjustments is made to these increased income tax rates.
} 
however, the shift to the EET regime generates larger average welfare compared to the other policy reforms.

\subsection{Equity effects}

To examine the equity effects of the superannuation taxation reforms, we use the concepts of equivalent variation, net income shares for household quintiles and of the Gini coefficient that is calculated using net incomes. The first equity measure - equivalent variation - provides the distributional welfare effects across the five income types of households (i.e., measuring the effects on vertical equity) and across different generations (i.e., measuring the effects on inter-generational equity). In particular, equivalent variation for the given generation measures the percentage increase in this generation's wealth, which brings about the proportional increase in consumption and leisure in each year of remaining life needed in the benchmark scenario to produce the realised remaining lifetime utility in the reform scenario (see Auerbach and Kotlikoff, 1987, p.87).

Table 4: Welfare Implications of Superannuation Tax Reforms (Percentage Changes in Remaining Utility from Initial Steady State Solution)

\begin{tabular}{|c|c|c|c|c|c|c|c|c|}
\hline \multirow{2}{*}{$\begin{array}{c}\text { Age in } \\
2010\end{array}$} & \multicolumn{4}{|c|}{ (i) Consumption tax adjustments } & \multicolumn{4}{|c|}{ (ii) Income tax adjustments } \\
\hline & $\begin{array}{c}\text { Lower } \\
\text { income[a] }\end{array}$ & $\begin{array}{c}\text { Middle } \\
\text { Income }[\mathrm{b}]\end{array}$ & $\begin{array}{c}\text { Higher } \\
\text { income }[\mathrm{c}]\end{array}$ & $\begin{array}{c}\text { Average } \\
\text { welfare[d] }\end{array}$ & $\begin{array}{c}\text { Lower } \\
\text { income[a] }\end{array}$ & $\begin{array}{c}\text { Middle } \\
\text { Income }[\mathrm{b}]\end{array}$ & $\begin{array}{c}\text { Higher } \\
\text { income }[\mathrm{c}]\end{array}$ & $\begin{array}{c}\text { Average } \\
\text { welfare[d] }\end{array}$ \\
\hline \multicolumn{9}{|c|}{ Shift to the EET tax regime } \\
\hline 80 & -0.890 & -3.036 & -5.519 & -3.171 & -1.009 & -3.083 & -5.450 & -3.200 \\
\hline 40 & 0.048 & -0.330 & -0.845 & -0.385 & -0.107 & -0.362 & -0.692 & -0.392 \\
\hline 20 & 0.405 & 0.310 & 0.141 & 0.280 & 0.266 & 0.289 & 0.301 & 0.285 \\
\hline-80 & 0.492 & 0.408 & 0.267 & 0.385 & 0.375 & 0.444 & 0.529 & 0.451 \\
\hline \multicolumn{9}{|c|}{ Shift to the TEE tax regime } \\
\hline 80 & 0.228 & 0.220 & 0.213 & 0.220 & 0.114 & 0.068 & 0.037 & 0.074 \\
\hline 40 & 0.339 & 0.161 & 0.005 & 0.170 & 0.259 & 0.166 & 0.119 & 0.185 \\
\hline 20 & 0.317 & 0.101 & -0.101 & 0.107 & 0.264 & 0.108 & -0.010 & 0.123 \\
\hline-80 & 0.216 & 0.003 & -0.175 & 0.017 & 0.226 & 0.000 & -0.195 & 0.012 \\
\hline \multicolumn{9}{|c|}{ Shift to the AFTS proposal } \\
\hline 80 & -0.039 & -0.117 & -0.160 & -0.103 & -0.036 & -0.118 & -0.164 & -0.103 \\
\hline 60 & -0.184 & -0.343 & -0.506 & -0.344 & -0.161 & -0.309 & -0.465 & -0.312 \\
\hline 20 & 0.315 & 0.125 & -0.045 & 0.133 & 0.365 & 0.136 & -0.092 & 0.137 \\
\hline-80 & 0.248 & 0.059 & -0.090 & 0.075 & 0.325 & 0.032 & -0.259 & 0.033 \\
\hline
\end{tabular}

Notes: [a] Average value for lowest and second quintiles; [b] Value for third quintile; [c] Average value for fourth and highest quintiles; [d] Average value across all income quintiles.

The distributional welfare effects of the examined superannuation taxation reforms are reported in Table 4 . These effects are presented as percentage changes in remaining utility for generations of different ages at the time of the reform and for three income 
types of households, assuming either consumption or income tax adjustments to balance the government budget. ${ }^{16,17}$ There are two main observations that can be drawn for the intra-generational implications. First, under the consumption tax adjustments, the key result is that all three reforms improve intra-generational or vertical equity, depicted by larger (smaller) gains (losses) in welfare for lower income types of households relative to those for higher income households. For instance, the shift to the EET tax regime generates the welfare loss of 0.89 percent for lower income households aged 80 years at the time of the reform, but the welfare loss for higher income types of the same age is 5.52 percent. In the long run, lower income households gain in welfare about 0.49 percent, compared to 0.27 percent gain for higher income types. Under the shift to the TEE regime, future born generations of lower income quintiles gain in welfare 0.22 percent, while higher income types attain the welfare loss of about 0.18 percent. These improvements in vertical equity are driven by the progressive taxation of superannuation benefits or contributions, which outweighs the elimination of the concessional tax on fund earnings that favours higher income types.

Second, the choice of budget-balancing tax instruments also plays an important role for the intra-generational implications. In particular, reduced (increased) budget balancing income tax rates are more (less) beneficial for welfare of higher income types, while reduced (increased) budget balancing consumption taxes are more (less) beneficial for welfare of lower income types. ${ }^{18}$ For example, under the shift to the EET regime with reduced income tax rates, the long run welfare gain for higher income types is 0.53 percent, compared to the gain of 0.27 percent for higher income types under the assumption of consumption tax adjustments with the lower consumption tax rate. On the other hand, the long run welfare gain for lower income types under the AFTS proposal with increased income tax rates is 0.36 percent, compared to the long run gain of 0.25 percent for these income types under the AFTS proposal with the increased consumption tax rate.

\footnotetext{
${ }^{16}$ Note that the youngest generation at the time of the reforms is aged 21 years, which is the assumed entry age in the model. All the generations aged 20 years and younger are those born in the succeeding transitional years. The results for the generation of age -80 in year 2010 (i.e., generation born in 2110) approximate the long run welfare effects.

${ }^{17}$ Our model assumes five income types of households. The welfare effects on lower income, middle income and higher income households in Table 4 are presented as the average effect for the lowest and second quintiles, the effect on the third quintile and the average effect for the fourth and highest quintiles, respectively.

${ }^{18}$ Recall that by reduced income tax rates we mean budget-balancing reductions in income tax rates that on average are higher under all three superannuation tax reforms.
} 
Table 4 also shows the inter-generational equity implications that differ among the superannuation taxation reforms. Under the EET tax regime, older generations receiving (or close to the age of receiving) the superannuation benefits experience welfare losses, with the average welfare loss for generations aged 80 years at the time of the reforms being 3.18 percent (or 3.20 percent with income tax adjustments). In contrast, future born generations gain in welfare, with the long run welfare gain of 0.39 percent (or 0.45 percent with income tax adjustments). The long run gains indicate that the resulting decreases in budget balancing consumption or income tax rates and significantly larger assets offset negative effects of marginal income tax rates applied to superannuation withdrawals. On the contrary, the shift to the TEE regime increases welfare of older generations due to initially reduced consumption or income tax rates. In the long term, the average welfare gain is smaller under this policy because of lower welfare for higher income households who bear most of the burden of the progressive income taxation applied to their superannuation contributions. ${ }^{19}$

Table 5: Effects of Superannuation Tax Reforms on Income Shares and Gini Coefficient (Percentage Changes in Net Income Shares and Gini Coefficient from Initial Steady State Solution)

\begin{tabular}{|c|c|c|c|c|c|c|c|c|}
\hline \multirow[b]{2}{*}{ Period } & \multicolumn{4}{|c|}{ (i) Consumption tax adjustments } & \multicolumn{4}{|c|}{ (ii) Income tax adjustments } \\
\hline & $\begin{array}{c}\text { Lower } \\
\text { income[a] }\end{array}$ & $\begin{array}{c}\text { Middle } \\
\text { Income }[\mathrm{b}]\end{array}$ & $\begin{array}{c}\text { Higher } \\
\text { income }[\mathrm{c}]\end{array}$ & $\begin{array}{c}\text { Gini } \\
\text { coefficient }\end{array}$ & $\begin{array}{c}\text { Lower } \\
\text { income[a] }\end{array}$ & $\begin{array}{c}\text { Middle } \\
\text { Income }[\mathrm{b}]\end{array}$ & $\begin{array}{c}\text { Higher } \\
\text { income }[\mathrm{c}]\end{array}$ & $\begin{array}{c}\text { Gini } \\
\text { coefficient }\end{array}$ \\
\hline \multicolumn{9}{|c|}{ Shift to the EET tax regime } \\
\hline 2010 & 0.855 & 0.220 & -0.365 & -0.935 & 0.400 & 0.118 & -0.216 & -0.482 \\
\hline 2015 & 0.926 & 0.193 & -0.347 & -0.936 & 0.480 & 0.091 & -0.202 & -0.485 \\
\hline 2030 & 1.174 & 0.462 & -0.433 & -1.308 & 0.967 & 0.404 & -0.367 & -1.081 \\
\hline Long run & 1.007 & 0.414 & -0.370 & -1.126 & 0.601 & 0.306 & -0.245 & -0.686 \\
\hline \multicolumn{9}{|c|}{ Shift to the TEE tax regime } \\
\hline 2010 & 2.128 & 0.187 & -0.652 & -1.899 & 1.710 & 0.120 & -0.517 & -1.504 \\
\hline 2015 & 2.156 & 0.145 & -0.638 & -1.908 & 1.792 & 0.098 & -0.524 & -1.569 \\
\hline 2030 & 1.865 & -0.026 & -0.473 & -1.618 & 1.893 & -0.013 & -0.474 & -1.673 \\
\hline Long run & 1.717 & -0.042 & -0.456 & -1.390 & 1.743 & -0.041 & -0.464 & -1.412 \\
\hline \multicolumn{9}{|c|}{ Shift to the AFTS proposal } \\
\hline 2010 & 1.686 & 0.066 & -0.508 & -1.431 & 1.530 & 0.023 & -0.456 & -1.266 \\
\hline 2015 & 1.713 & 0.049 & -0.501 & -1.457 & 1.607 & 0.017 & -0.466 & -1.341 \\
\hline 2030 & 1.690 & -0.015 & -0.443 & -1.451 & 1.853 & -0.019 & -0.488 & -1.583 \\
\hline Long run & 1.455 & -0.096 & -0.379 & -1.133 & 1.664 & -0.085 & -0.440 & -1.311 \\
\hline
\end{tabular}

\footnotetext{
${ }^{19}$ Similar inter-generational welfare effects are obtained by Fehr et al. (2008) for the policy introducing voluntary front-loaded and back-loaded accounts. The differences in their results between the two types of tax-preferred accounts come mainly from the general equilibrium effects on the assumed budget balancing policy instrument rather than through direct effects on households from the taxation applied to these voluntary accounts.
} 
The other two equity measures for which we provide results are the net income shares for five household types and the Gini coefficient. The percentage changes in net income shares and in the Gini coefficient are presented in Table 5. Similar to the distributional welfare implications, all three reforms increase (reduce) net income shares for lower (higher) income types, thus reducing the Gini coefficient. Under the shift to the EET regime, the Gini coefficient falls by 0.94 percent (or by 0.48 percent with income tax adjustments) on impacts and by 1.13 percent (or by 0.69 percent with income tax adjustments) in the long term. The improvements in vertical equity during the transition path result from the transitional increases in the net income shares for lower income types. The opposite transitional effects on vertical equity result from the shift to the TEE regime and also from adopting the AFTS proposal with consumption tax adjustments, with the decreases in the Gini coefficient being larger in the short term than in the long run. For example, under the TEE regime, the Gini coefficient falls by about 1.9 percent (or by 1.5 percent with income tax adjustments) on impact and by 1.39 percent (or by 1.41 percent with income tax adjustments) in the long run.

\subsection{Macroeconomic effects}

Macroeconomic or aggregate variables are obtained as weighted averages of optimal household behaviour, where the weights are the constant cohort and income type shares. The macroeconomic effects of the superannuation tax reforms are displayed in Table 6 as percentage changes in the selected per capita variables in the selected years of the transition from the benchmark steady state solution. Note that the reforms are assumed to be implemented in 2010, with the results for that year depicting the impact effect of the reforms. We also present the results for 2030 and the long run effects of the policy reforms. In the discussion of the macroeconomic results we concentrate on the implications for the asset accumulation and capital, the goods market, the labour market and for the main government indicators. 
Table 6: Macroeconomic Implications of Superannuation Tax Reforms (Percentage Changes in Selected Per Capita Variables from Initial Steady State Solution)

\begin{tabular}{|c|c|c|c|c|c|c|}
\hline \multirow{2}{*}{ Variable } & \multicolumn{3}{|c|}{ (i) Consumption tax adjustments } & \multicolumn{3}{|c|}{ (ii) Income tax adjustments } \\
\hline & EET & TEE & AFTS & EET & TEE & AFTS \\
\hline \multicolumn{7}{|l|}{ Domestic assets } \\
\hline 2010 & 0.00 & 0.00 & 0.00 & 0.00 & 0.00 & 0.00 \\
\hline 2030 & 19.05 & 3.03 & 3.64 & 20.82 & 4.10 & 3.09 \\
\hline Long run & 21.79 & 4.37 & 4.85 & 24.84 & 4.16 & 3.00 \\
\hline \multicolumn{7}{|l|}{ Labour supply } \\
\hline 2010 & 1.92 & -0.53 & -0.11 & 2.98 & 0.39 & 0.18 \\
\hline 2030 & -1.81 & -0.81 & -0.63 & -1.54 & -0.94 & -1.09 \\
\hline Long run & -2.24 & -1.10 & -0.84 & -1.76 & -1.14 & -1.15 \\
\hline \multicolumn{7}{|l|}{ Output (GDP) } \\
\hline 2010 & 1.17 & -0.33 & -0.06 & 1.81 & 0.24 & 0.11 \\
\hline 2030 & -1.72 & -0.81 & -0.61 & -1.41 & -0.91 & -1.03 \\
\hline Long run & -2.24 & -1.10 & -0.84 & -1.76 & -1.14 & -1.15 \\
\hline \multicolumn{7}{|c|}{ Gross national product (GNP) } \\
\hline 2010 & 1.17 & -0.28 & -0.04 & 1.77 & 0.25 & 0.14 \\
\hline 2030 & 0.37 & -0.41 & -0.18 & 0.81 & -0.39 & -0.61 \\
\hline Long run & 0.16 & -0.56 & -0.28 & 0.89 & -0.62 & -0.74 \\
\hline \multicolumn{7}{|l|}{ Consumption } \\
\hline 2010 & -3.64 & -0.48 & -0.44 & -3.55 & -0.46 & -0.43 \\
\hline 2030 & -1.23 & -1.15 & -0.83 & -0.67 & -0.96 & -1.09 \\
\hline Long run & -0.57 & -0.89 & -0.54 & 0.29 & -0.96 & -1.08 \\
\hline \multicolumn{7}{|c|}{ Pension expenditure } \\
\hline 2010 & 0.63 & 0.02 & 0.03 & 0.57 & 0.01 & 0.04 \\
\hline 2030 & -2.84 & -0.49 & 0.01 & -3.15 & -0.61 & 0.09 \\
\hline Long run & -4.52 & -0.93 & -0.67 & -5.11 & -0.89 & -0.29 \\
\hline \multicolumn{7}{|c|}{ Income tax revenue } \\
\hline 2010 & 13.67 & 12.33 & 6.90 & 8.19 & 8.39 & 6.19 \\
\hline 2030 & 11.30 & 9.32 & 4.44 & 8.58 & 9.00 & 6.76 \\
\hline Long run & 12.16 & 8.77 & 3.90 & 7.98 & 9.11 & 6.69 \\
\hline \multicolumn{7}{|l|}{ Tax rate [a] } \\
\hline 2010 & -16.43 & -11.14 & -1.66 & -5.63 & -4.26 & -0.88 \\
\hline 2030 & -7.63 & -0.84 & 6.45 & -3.12 & -0.34 & 2.80 \\
\hline Long run & -11.33 & 0.93 & 7.55 & -4.85 & 0.40 & 3.29 \\
\hline
\end{tabular}

Notes: [a] These are percentage changes in either the consumption tax rate or income taxation imposed on taxable income that includes superannuation benefits (the EET regime) or contributions (the TEE regime and AFTS proposal).

The removal of the superannuation contribution tax rate, combined with the full elimination (under both the EET and TEE regimes) or the partial elimination (under the AFTS proposal) of fund earning tax implies larger superannuation assets, which generate the reported increases in total domestic assets. The magnitude of these increases, however, is largely different among the three reforms. Similar differences in the effects on national wealth arising from introduction of voluntary front- and back-loaded retirement accounts are derived by Fehr et al. (2008). Under the EET regime, the long run increase in total wealth is 21.78 percent (or 24.84 percent with income tax adjustments), which is due to greater superannuation assets and also to increased private non-superannuation assets. 
Increased private assets are due to lower consumption expenditures and initially higher labour supply. As for the TEE regime and the AFTS proposal, the increases in total domestic assets are moderated by decreases in private assets that are affected by higher income taxes faced younger generations. ${ }^{20}$ While the total wealth increases, the effects of the superannuation taxation reforms for the capital stock per capita (not displayed) are negative. In the short and medium term, the capital decreases are caused by lower capital prices (not displayed) but in the long term, these negative effects are entirely driven by lower labour input. Hence, the increases in household saving are not invested in the domestic capital stock but exported abroad, leading to substantial reductions in net foreign debt.

The examined radical changes to superannuation taxation have significant implications for household labour supply. As shown in Table 6, the effects of the TEE regime and the AFTS proposal on per capita labour supply are negative over the entire transition paths. The lower average labour supply is due to reduced working hours of middle-age and older working households that face increased income tax rates as contributions are treated under the progressive income taxation. The relatively more favourable outcome for per capita labour supply arising from the AFTS proposal is caused by the uniform 15 percent tax offset to superannuation contributions that effectively reduces income tax rates (relative to the rates under the TEE regime). On the other hand, the shift to the EET regime leads initially to higher per capita labour supply, which in 2010 increases by 1.92 percent with consumption tax adjustments or by 2.98 percent with income tax adjustments. This is because the current middle-age and older working households supply more labour in order to boost the superannuation savings. In the succeeding years of the transition, the increases in average labour supply disappear, with the average labour supply falling by 2.24 percent (or by 1.76 percent with income tax adjustments) in the long term, which is due mainly to the dominating income effect of significantly larger asset holdings. ${ }^{21}$

\footnotetext{
${ }^{20}$ Recall that we impose borrowing constrains on all households so they cannot borrow against their superannuation assets. Removing the borrowing constraints would generate a larger superannuation offset (i.e., reduction in private non-superannuation assets) and smaller increases in total wealth for all three examined reforms. Creedy and Guest (2008b) allow for borrowing, which partly explains lower saving generated by their policy simulation of removing the concessional tax rate on benefits.

${ }^{21}$ The wage rate (not displayed) is unchanged in the long term in this small open economy model but during the transition it moves in the opposite direction to the changes in average labour supply (i.e., higher labour supply by households leads to a lower wage rate paid by firms).
} 
The output (or GDP) is produced, using the capital stock and labour supply, and so the effects of the reforms on output follow the changes in these two inputs to production. Table 5 indicates that only under the shift to the EET regime in the short and medium terms, output increases because of higher average labour supply. The effects on national income (or GNP) that equals the output less the interest payments on foreign debt are more favourable because of lower foreign debt. In fact, the national income is higher over the entire transition and in the long term as a result of the shift to the EET regime. The largest component of output is consumption, which is measured in per capita terms as all the other macroeconomic variables. As shown, all three reforms have negative effects on per capita consumption. Under the EET regime, average consumption decreases significantly by about 3.6 percent on impact, caused by lower consumption of the current elderly that now have their superannuation benefits taxed as ordinary income. However, there are improvements in per capita consumption during the transition due to greater accumulated assets. By contrast, the shift to the TEE regime and the AFTS proposal generate relatively higher consumption in the short run than in the long run, which is driven mainly by the budget equilibrating changes in the consumption or income tax rates over the transition. ${ }^{22}$

The simulation results also show that all three reforms reduce reliance of the elderly on publicly provided age pension. This is because of the means testing of larger accumulated assets and asset incomes in retirement. The decline in the age pension expenditures is especially significant for the shift to the EET regime, generating the long run fall in public pension costs of 4.52 percent with consumption tax adjustments or of 5.11 percent with income tax adjustments. As expected, the receipts from the income taxation increase under all three reforms as either benefits or contributions are treated as ordinary taxable income. ${ }^{23}$ Assuming the consumption tax adjustments, the effects on income tax receipts are quite similar for both the EET and TEE regimes in the short run, but over the transition, the shift to the TEE regime leads to greater decreases in income tax revenues. The decreases are caused by the higher income tax rates faced by middle-age households

\footnotetext{
${ }^{22}$ The effects on the other components of aggregate demand are not displayed. In brief, government or public consumption is kept constant over the entire transition and the policy effects on investment demand are similar to those in the capital stock. The external demand or net export balances output supply with domestic demand and under all three reforms, it decreases in the long run as the output falls more than domestic demand.

${ }^{23}$ Note that lower income tax revenues under the AFTS proposal relative to the other two reforms are due to the 15 percent superannuation contribution offset.
} 
that lower their labour supply, private assets and asset incomes. The increased income tax revenues allow for a lower consumption tax rate that is assumed to balance government expenditures and tax revenues. In the short term, the consumption tax rate declines under all three examined reforms. However, relative to the impact effects, the consumption tax rate increases and it is 0.93 percent and 7.55 percent higher for the TEE regime and the AFST proposal, respectively. These increases are caused partly by declining intakes from personal income taxation, corporation taxation (that largely follows the effects on output) and declining average consumption that affects overall consumption tax revenues. The relatively higher consumption or income taxes for the AFTS proposal are due the uniform 15 percent contribution tax offset.

\section{$5 \quad$ Higher superannuation contributions}

This section considers the long run effects of the three reforms to superannuation taxation, assuming the 12 percent superannuation guarantee (SG) rate. In 2010, the Australian government announced that the SG rate will be gradually increased, reaching 12 percent of gross wages by July 2019. The macroeconomic and welfare effects of the gradual increases in the SG rate were examined by Kudrna and Woodland (2013). Similarly to Kudrna and Woodland (2013), we find that the higher SG rate directly increases superannuation assets. The resulting increase in total assets and interest income upon reaching pension eligibility age reduce an overall reliance on the age pension support in retirement. Although the government's pension expenditures fall as a result of the increased contribution rate, income tax revenues decrease (due to lower labour earnings as a result of the wage drop and lower investment earnings caused by the superannuation offset) and have to be compensated by an increase in the consumption tax rate or alternatively by an increase in the average income tax rate. In terms of the welfare effects, the increased SG rate increases welfare for higher income types, whereas lower income types with no preferential tax treatment of their superannuation suffer from welfare losses because of the reduction in the market wage rate and the increase consumption or income tax rates that compensate for higher superannuation tax concessions. 
Table 7: Long Run Effects of Superannuation Tax Reforms with 12\% SG Rate (Percentage Changes in Selected Variables from New Steady State Solution with 12\% SG Rate)

\begin{tabular}{|c|c|c|c|c|c|c|}
\hline \multirow{2}{*}{ Variable } & \multicolumn{3}{|c|}{ (i) Consumption tax adjustments } & \multicolumn{3}{|c|}{ (ii)Income tax adjustments } \\
\hline & EET & TEE & AFTS & EET & TEE & AFTS \\
\hline \multicolumn{7}{|l|}{ Macro implications } \\
\hline Domestic assets & 23.48 & 12.76 & 10.41 & 26.99 & 14.12 & 11.00 \\
\hline Labour supply & -2.43 & -2.23 & -1.56 & -1.69 & -2.42 & -2.24 \\
\hline Consumption & -0.40 & -1.29 & -0.74 & 0.78 & -1.40 & -1.51 \\
\hline Pension expenditure & -5.43 & -2.41 & -1.47 & -5.51 & -2.25 & -1.29 \\
\hline Income tax revenue & 17.87 & 13.11 & 6.18 & 10.52 & 12.31 & 9.19 \\
\hline Tax rate $[\mathrm{a}]$ & -12.07 & 0.75 & 7.55 & -7.85 & -0.82 & 3.06 \\
\hline \multicolumn{7}{|l|}{ Welfare effects } \\
\hline Lower income $[\mathrm{b}]$ & 0.72 & 0.35 & 0.36 & 0.49 & 0.31 & 0.45 \\
\hline Middle income $[\mathrm{c}]$ & 0.55 & 0.09 & 0.14 & 0.50 & 0.06 & 0.12 \\
\hline Higher income [d] & 0.36 & -0.20 & -0.08 & 0.72 & -0.21 & -0.28 \\
\hline Average welfare & 0.54 & 0.08 & 0.14 & 0.58 & 0.05 & 0.09 \\
\hline \multicolumn{7}{|l|}{ Income shares } \\
\hline Lower income [b] & 1.45 & 1.96 & 1.58 & 0.88 & 1.93 & 1.83 \\
\hline Middle income $[\mathrm{c}]$ & 0.53 & -0.01 & -0.11 & 0.30 & -0.01 & -0.05 \\
\hline Higher income [d] & -0.51 & -0.56 & -0.43 & -0.29 & -0.54 & -0.52 \\
\hline Gini coefficient & -1.53 & -1.55 & -1.16 & -0.92 & -1.54 & -1.42 \\
\hline
\end{tabular}

The long run effects of the superannuation taxation reforms with the 12 percent SG rate are reported Table 7 as the percentage changes in the selected variables from the new (long run) steady state solution with the higher contribution rate. The comparison with the long run effects of the superannuation taxation reforms with the 9 percent SG rate presented in the previous section reveals that the long run effects presented here, although different quantitatively, are broadly the same qualitatively in the sense of having the same direction of change in most macroeconomic and welfare variables. That is, the examined superannuation taxation reforms with the 12 percent SG rate continue to yield greater domestic assets, lower pension expenditures, improved intragenerational equity and reduced income inequality. The only exception is the shift to the EET regime with income tax adjustments, where the long run welfare gains are greater for higher income types compared to the gains for income types (i.e., vertical equity worsens), which is due to the budget equilibrating reduction in income tax rates (that favours higher income types). The larger long run increases in domestic assets compared to those reported in Section 4 are due to smaller superannuation offsets (i.e., reductions in ordinary non-superannuation assets). As mentioned, the increase SG rate results in larger superannuation savings, which offset (displace) other savings. Additional increases in the superannuation assets arising from the superannuation taxation reforms then lead 
to smaller superannuation offsets and thus larger increases in total assets compared to those with the 9 percent rate.

\section{Concluding remarks}

In this paper we have examined hypothetical but radical reforms to superannuation taxation by using a computable OLG model that incorporates essential features of the Australian retirement income and taxation policy settings. These reforms include (i) the shift to the EET taxation regime; (ii) the shift to the TEE regime and (iii) adopting the AFTS proposal on the taxation of superannuation. The first two reforms represent the replacements of the existing concessional superannuation taxation with the taxation regimes commonly applied to private pension pillars in other countries, where either benefits or contributions are treated as ordinary incomes and tax progressively. The third reform is a variant of the shift to the TEE regime, which includes a 15 percent refundable contribution tax offset and halving (but not fully eliminating) the effective tax rate on investment earnings by the superannuation fund.

The major objective of the paper was to assess whether and to what extent the reforms improve vertical (or intra-generational) equity of the superannuation system, which currently provides tax concessions mainly to wealthy households, with lower income households deriving little or no benefits (AFTS, 2010). Our simulation results indicate that all three reforms generate positive effects on vertical equity in the short, medium and long terms, supporting the proposals to impose progressive income taxes on either superannuation contributions or benefits (see ASFA (1998), Ingles (2009) and AFTS, 2010). The welfare gains (losses) are greater (smaller) for lower income households relative to those experienced by higher income households. The net income shares for lower income households also improve, while the shares for higher income household are smaller and the Gini coefficient decrease under all the examined reforms. To rank the policy reforms based on the values obtained for the Gini coefficient, the most effective policy to reduce income inequality would be the shift towards the TEE regime, followed by the AFTS proposal and the EET regime.

The model is also capable of evaluating the inter-generational implications of the reforms. It is shown that the effects on inter-generational equity obtained from the shift 
to the EET taxation regime are very different from those caused by the TEE regime and the AFTS proposal. Under the shift to the EET regime, older generations suffer from large welfare losses as their private pensions are treated as regular income and taxed at marginal income tax rates. However, long run improvements in welfare arising from the shift to the EET regime are higher for all income classes of households compared to the other two taxation reforms, driven by significant increases in the income tax revenue that leads to lower consumption taxes.

The removal of the existing concessional taxes paid by superannuation funds on mandatory contributions and interest earnings (i.e., part of each of the examined reforms) implies larger superannuation assets accumulations, which cause the national assets and household saving to increase. The implied larger assets and asset incomes in retirement are assessed under the age pension means test, reducing age pension payments for some households and the overall pension expenditure to the government. Hence, the reforms increase self-funding and reduce reliance on the age pension for many pensioners. The effects on average labour supply, however, are negative, arising from the income effect of increased life-cycle assets for the EET regime and from higher income tax rates faced by young and middle-age generations for the TEE regime and the AFTS proposal.

Any modeling analysis such as that employed here is subject to limitations. First, it should be empahsised that the simulation of the examined reforms to superannuation taxation were undertaken in the environment of the fully mature superannuation system, while the existing system is still in the transition, with the mandatory superannuation being introduced in 1992 with initial three percent contributions. And so, if we targeted the current values for superannuation assets and superannuation taxation revenues in the benchmark simulation, the effects generated by the reform would change from those presented. For example, eliminating the concessional tax rates on superannuation would require smaller increases in other taxes to balance the government budget, given the overestimated intakes from superannuation taxes generated by our benchmark steady state solution. Similarly, the shift to the EET regime is likely to lead to smaller increases in income tax revenues in the short and medium run than those presented, as the current superannuation balances are not as large as predicted by the model. Second, the present model features stationary demographics with a constant annual growth rate of total population and a time-invariant population age distribution. Implementing population 
ageing that si projected to accelerate in the next few decade would also change the obtained results. For instance, the increases in the income taxation revenues resulting from the shift to the TEE regime would not be as large because of the projected decreases in the shares of younger cohorts in the total population whose contributions would be taxed under the income taxation. On the other hand, the shift to the EET regime would lead to larger income tax revenues in the longer run due to expected increases in the older cohort shares. Hence, it would be more realistic if the model incorporates non-stationary demographics with the increasing share of older cohorts in future years.

\section{References}

[1] Altig, D., Auerbach, A., Kotlikoff, L, Smetters, K. and Walisser, J. (2001), "Simulating Fundamental Tax Reform in the United States", American Economic Review, $91(3), 574-595$.

[2] Atkinson, M.E., Creedy, J. and Knox, D. (1999), "Some Implications of Changing the Tax Basis for Pension Funds", Fiscal Studies, 20 (2), 189-203.

[3] Auerbach, A. J. and Kotlikoff, L. (1987), Dynamic Fiscal Policy, Cambridge University Press, Cambridge.

[4] Australian Bureau of Statistics [ABS] (2007), Government Benefits, Taxes and Household Income, Cat. No. 6537.0, Australian Government Publishing Service, Canberra.

[5] ABS (2010a), Life Tables, Australia 2007-2009, ABS Cat. No. 3302.0.55.001, Australian Government Publishing Service, Canberra.

[6] ABS (2010b), Australian System of National Accounts 2009-10, ABS Cat. No. 5204.0, Australian Government Publishing Service, Canberra.

[7] Australia's Future Tax System [AFTS] (2008), Retirement Income consultation Paper, Commonwealth of Australia, Canberra.

[8] AFTS (2010), Final Report, Commonwealth of Australia, Canberra. 
[9] Australian Superannuation Fund Association (1998), Blue Skies ASFA's Blueprint for a National Retirement Incomes Policy, Sydney.

[10] Bateman, H. and Kingston, G. (2007), Superannuation and Personal Income Tax Reform, Australian Tax Forum, 22 (3), 137-161.

[11] Bateman, H. and Piggott, J. (2011), "Too Much Risk to Insure? The Australian (non-) Market for Annuities", in O. Mitchell, J. Piggott and N. Takayama (eds.), Securing Lifelong Retirement Income, Oxford University Press.

[12] Clare, R. (2006), The Benefits, Revenue Cost, and Implications for Individuals and the Economy of Abolishing the Contributions Tax, ASFA Research Centre, Sydney.

[13] Cho, S-W. and Sane, R. (2011), "Means-Tested Age Pension and Homeownership: Is there a Link?", Macroeconomic Dynamics, forthcoming.

[14] Commonwealth of Australia (2011), Budget Strategy and Outlook 2010-11, Budget Paper No. 1. Commonwealth of Australia, Canberra.

[15] Creedy, J. and Guest, R. (2008a), "The Labour Supply and Savings Effects of Superannuation Tax Changes", Australian Economic Papers, 47 (1), 1-14.

[16] Creedy, J. and Guest, R. (2008b), "Changes in the Taxation of Private Pensions: Macroeconomic and Welfare Effects", Journal of Policy Modelling, 30 (5), 693-712.

[17] Davidson, S. and Guest, R. (2007), "Superannuation Tax Reform: Fiscal Consequences", Agenda, 14 (1), 5-16.

[18] Department of Families, Community Services and Indigenous Affairs [FaCSIA] (2007), Retirement Income Streams, Commonwealth of Australia, Canberra.

[19] Doyle, S., Kingston, G. and Piggott, J. (1999), "Taxing Super", Australian Economic Review, 32 (3), 207-218.

[20] Fehr, H. (2000), "Pension Reform During the Demographic Transition", Scandinavian Journal of Economics, 102 (3), 419-443.

[21] Fehr, H., Habermann, Ch. and Kindermann, F. (2008), "Tax-Favored Retirement Accounts: Are They Efficient in Increasing Savings and Economic Growth?", FinanzArchiv: Public Finance Analysis, 64 (2), 171-198. 
[22] Horne, J. (2002), Taxation of Superannuation in Australia: An Assessment of Reform Proposals, Working Paper, Macquarie University, Australia.

[23] Institute of Actuaries of Australia [IAA] (2006), "Taxation of Superannuation in Australia: A Future Revenue Problem?", available online at: http://www.actuaries.asn.au.

[24] Ingles, D. (2009), The Great Superannuation Tax Concession Rort, Australia Institute, Research Paper, No. 61.

[25] Imrohoroglu, A., Imrohoroglu, S. and Joines, H. (1998), "The Effect of Tax-Favored Retirement Accounts on Capital Accumulations", American Economic Review, 88 (4), 749-768.

[26] Kingston, G. and Piggott, J. (1993), "A Ricardian Equivalence Theorem on the taxation of pension funds", Economics Letters, 42 (4), 399-403.

[27] Kudrna, G. and Woodland, A.(2011), "Implications of the 2009 Age Pension Reform in Australia: A Dynamic General Equilibrium Analysis", Economic Record, 87, 183201.

[28] Kudrna, G. and Woodland, A.(2013), "Macroeconomic and Welfare Effects of the 2010 Changes to Mandatory Superannuation", Economic Record, fortcoming.

[29] Kulish, M., Smith, K. and Kent, Ch. (2010), "Ageing, Retirement and Savings: A General Equilibrium Analysis", The B.E. Journal of Economics, 10 (1).

[30] Nishiyama, S. (2011), "The Budgetary and Welfare Effects of the Tax-deferred Retirement Saving Accounts", Journal of Public Economics, 95, 1561-1578.

[31] OECD (2011), Pension at a Glance: Public Policies across OECD Countries, Paris.

[32] Reilly, R., Milne, W. and Zhao, S. (2005), "Quality-adjusted labour inputs", ABS Research Paper No. 1351.0.55.010, Canberra.

[33] Tran, Ch. and Woodland, A. (2011), Trade-Offs in Means Tested Pension Design, ANUCBE School of Eocnomics Working Paper, Australian National University, Canberra. 
[34] Yoo, K.Y. and de Serres, A. (2004), The Tax Treatment of Private Pension Savings in OECD Countries and the Net Tax Cost per Unit of Contributions to Tax Favoured Schemes, OECD Workinf Paper No.406, Paris. 